Corresponding author:

\begin{tabular}{lll}
\hline Name & Address & \\
\hline Telephone number & FAX number & Email address \\
$* *$ Title of Manuscript: & & \\
$* *$ Name $(\mathrm{s})$ of author $(\mathrm{s}):$ &
\end{tabular}

A signature below certifies agreement with the corresponding author designation and acceptance of this agreement. If there is more than one author, each must sign this agreement.

\title{
I. CONDITIONS OF SUBMISSION
}

A. Scope of Agreement: Unless otherwise specified, the terms of this Agreement apply to the Manuscript and any and all supplemental digital content (SDC) (audio, video, and other data files, the forms of which may vary) submitted by the author(s) for online publication with the Manuscript. The Manuscript and the SDC hereinafter are referred to collectively as the "Work."

B. Sole Submission of Original Work: Each author represents and warrants that the Work is the author's original work (except for any material from previously copyrighted works obtained by permission or assignment and credited as such); that none of the information has been published previously or is under consideration by another publication; that upon publication, the Work shall not infringe any copyright, invade any right of privacy, contain any libelous material, or infringe or violate any other right of any person or entity. Each author represents and warrants that the following is a complete description of all material contained in the Work, including any SDC, which is not original and/or in which the authors are not able to transfer copyright (attach additional pages if necessary):

C. Approval Verification: Each author represents and warrants that investigations involving human or animal subjects received the appropriate institutional approval and agrees to provide evidence of such approval if requested. In addition, each author agrees to produce the data on which the Work is based for examination by the editors or their assignees should they request them.

D. Authorship Certification: Each author represents and warrants that he or she has fulfilled the definition of authorship given in the Instructions for Authors, participated in this study sufficiently to ensure its integrity and to take public responsibility for it, and approved the Work submitted to Obstetrics $\mathcal{E}$ Gynecology. Each author represents and warrants that all persons who contributed to the work reported in the Manuscript are identified as authors or are included in the acknowledgements.

E. Conflict of Interest Disclosure: Each author represents and warrants that he or she has no financial affiliation (eg, employment, direct payments, stock holdings, retainers, consultantships, patent-licensing arrangements, or honoraria) or involvement within the last 3 years with any commercial organization with potential financial interest in the subject or materials discussed in the Work, except as disclosed in an attachment to this document. Any other potential conflict of interest also is disclosed.

F. Journal Research: Works under consideration are sometimes enrolled in Obstetrics \& Gynecology research projects. When this is done, the identity of individual Works and authors is kept confidential. Each author hereby give consent for the Work to be used in such research.

G. Compliance with Privacy Laws: Each author represents and warrants that the Work complies with all applicable patient privacy laws (such as the Health Insurance Portability and Accountability Act of 1996, the regulations promulgated thereunder, and the Health Information Technology for Economic and Clinical Health Act of 2009, if applicable) and that the authors have obtained, prior to submission, any necessary patient authorizations. The corresponding author shall maintain such authorizations and shall inform the journal in a timely manner of any revocation by a patient of such authorization.

H. Identification of Patients: Each author represents and warrants that he or she has obtained a signed consent form from each patient described in a case report and each patient who is identifiable in a photograph or video. Obstetrics $\mathcal{E}^{\circ}$ Gynecology reserves the right to review the signed forms. Should the editorial office request copies of the signed forms, the corresponding author shall submit the forms in a timely manner.

I. Acknowledgments: Each author represents and warrants that all persons who contributed to the work reported in the Manuscript, but not sufficiently to be authors, are named in the acknowledgments and have given written permission to be named.

J. Manuscript Preparation Assistance: Each author represents and warrants that any and all document preparation assistance, including but not limited to topic development, data collection, analysis, writing, or editorial assistance, is disclosed in the acknowledgments.

K. Consideration: Each author hereby acknowledges that the publication of the Manuscript in a forthcoming edition of Obstetrics \& Gynecology constitutes the sole consideration due to each of the authors under this Agreement. 
L. Indemnification and Hold Harmless: Each author hereby agrees to indemnify, defend, and hold harmless the American College of Obstetricians and Gynecologists (ACOG), its directors, officers, agents, employees, affiliates, successors and assigns from and against all claims, actions, suits or other proceedings, and any and all losses, judgments, settlements, damages, expenses, liabilities (including liability assumed in contractual agreements with third parties), or other costs (including reasonable counsel fees, disbursements, and costs of settlement), arising from or in any way relating to the Work, or any breach, or alleged breach by any author of any of the provisions of this Agreement. If the Authors fail to promptly or diligently pursue any defense of any indemnified party, the indemnified parties, or any of them, may assume such defense at the expense of the Authors.

\section{COPYRIGHT}

A. Copyright Transfer: Each author hereby assigns, transfers, and otherwise conveys all rights, title, and interest in the Work, including all copyright ownership worldwide, in all languages, and in all forms of media now or hereafter known, including electronic media such as CDROM, Internet, and Intranet, for the full term and all extensions and renewals thereof, to ACOG. Each author acknowledges that, in addition to publishing the Work in Obstetrics $\mathbb{E}^{3}$ Gynecology, ACOG may use, publish, and distribute the Work in any manner or media in its sole discretion including, but not limited to, licensing the SDC to YouTube for inclusion on Obstetrics E Gynecology's YouTube channel. If ACOG and the editor should decide for any reason not to publish the Work in Obstetrics $\mathcal{E}$ Gynecology, one of them shall give prompt notice of the decision to the corresponding author, and this Agreement and each of the rights and obligations described herein shall terminate.

B. Work Made For Hire: If this Work, or any portion of it, was written in the course of the author(s)' employment as a "Work Made for Hire" as defined under U.S. Copyright Law, the Work is owned by the company/employer. The author must check the "Work for Hire" box after his or her signature and an authorized representative of the company/employer must also sign this form and state his or her title. In such case, the company/employer hereby assigns to ACOG, during the full term of copyright, all copyright in and to the submitted Work for the full term of copyright throughout the world as specified in Section II, paragraph A above.

C. Government Employees: If any author created this Work, or a portion of it, in the course of that author's employment by the United States Government, that author must check the "Government" box after his or her signature. A work prepared by a government employee as part of his or her official duties is called a "work of the U.S. Government" as it is not subject to copyright and the provisions of this Section II, paragraphs A and B, do not apply. If it is not prepared as part of the employee's official duties, it may be subject to copyright.

\section{DEPOSIT OF POSTPRINTS}

A. Author(s) Posting of Articles to an Institutional Repository: Obstetrics \& Gynecology will permit the author(s) to deposit a "postprint" (defined as the final Manuscript after peer-review and acceptance for publication but prior to the publisher's copyediting, design, formatting, and other services) on his/her personal Website, university's institutional repository, or employer's intranet, subject to the following:

1. The author(s) may only deposit the postprint, as designated by Obstetrics E Gynecology, and not any other version of the Manuscript.

2. The author(s) shall not update the postprint text or replace it with a proof or with the final published version.

3. Except as provided in this Section, the author $(\mathrm{s})$ shall not include the postprint or any other version of the article in any commercial website or in any repository other than as specified above.

4. The author(s) shall not display the postprint until 12 months after publication of the final article.

5. The author(s) must attach the following notice to the postprint: "This is a non-final version of an article published in final form in (provide complete journal citation)."

6. The author(s) shall provide a link in the postprint to the Obstetrics $\mathcal{E}$ Gynecology Internet site.

\section{B. Compliance With Certain Research Funding Agency Requirements:}

1. Authors of articles based on research funded by the National Institutes of Health (NIH), the Howard Hughes Medical Institute (HHMI), or the Wellcome Trust, are subject to the following policies:

a. NIH requires authors to deposit postprints based on NIH-funded research in the National Library of Medicine's (NLM) PubMed Central (PMC) within 12 months after publication of the final article.

b. HHMI requires authors to deposit postprints based on HHMI-funded research in NLM's PMC within 6 months after publication of the final article.

c. The Wellcome Trust requires authors to deposit postprints based on research funded by the Wellcome Trust in UK PubMed Central within 6 months after publication of the final article.

2. If the author(s) indicate at the bottom of this Agreement that the Manuscript is subject to a public access requirement, LWW will transmit the postprint of the Manuscript to NLM's PMC. The author(s) agree to the following:

a. Upon NIH request, it remains the legal responsibility of the author(s) to confirm with NIH the provenance of the Manuscript for purposes of deposit.

b. The author(s) shall not deposit their articles themselves.

c. The author(s) shall not alter the postprint already transmitted to NLM's PMC. 


\section{C. "Public Access Policy" Funding Disclosure}

Please disclose below if you have received funding for research on which your article is based from any of the following organizations:

$\square$ National Institutes of Health (NIH)

$\square$ Wellcome Trust

$\square$ Howard Hughes Medical Institute (HHMI)

$\square$ Other (please list):

$\square$ Other (please list):

Each author must complete and sign a copy of this form to indicate his/her acceptance of the terms of this Agreement. Please check the applicable boxes.

\section{Author:}

\section{Check if applicable (see Section II)}

$\square$ Work for Hire (see Section II.B). Representative of company/employer must sign below.

\begin{tabular}{|c|c|c|c|}
\hline \multirow{2}{*}{ Company/employer representative: } & Signature & Printed Name & Date \\
\hline & Title & Company/Em & \\
\hline
\end{tabular}

$\square$ Government (see Section II.C)

\section{Disclosure of Potential Conflicts of Interest}

$\square$ Yes, I have disclosed potential conflicts of interest (attached) (see Section I.E)

$\square$ No, I have no potential conflicts of interest to disclose (see Section I.E)

\section{Authorship}

In January 2014, Obstetrics $\&$ Gynecology adopted the ICMJE recommendations for authorship. Note that you must meet a minimum of four criteria to be an author. Individuals who do not qualify for authorship based on the ICJME recommendations will be listed in the Acknowledgments. Indicate your contributions to the Work by checking the applicable boxes:

$\square$ 1a) Substantial contributions to the conception or design of the Work

$\square$ 1b) Substantial contributions to the acquisition, analysis, or interpretation of data for the Work

$$
\text { and }
$$

$\square$ 2) Drafting the Work or revising it critically for important intellectual content

$\square$ 3) Final approval of the version to be published

$\square$ 4) Agreement to be accountable for all aspects of the Work in ensuring that questions related to the accuracy or integrity of any part of the Work are appropriately investigated and resolved 